\title{
Unpublished Master's and Lic. Phil. Theses Concerning American History in Finland, 1964-1968
}

Kalevi Ahoncn, Yhdysvaltain kauppamerenkulku Itamerella vuosina 1826 1856. (The Baltic Trade of the United States, 1826-1856).

JY, General history, 1968. 151 p.

Seppo Appelqvist, Yhdysvaltain ja YK:in Korean sodan politiilclca. (The United Stales, the United Nations and the War in Korea).

HY, Pol. sc., 1968.

Kirsti Kallio, Atlantin liitto Yhdysvaltain ja Ranskan välisenä Iriistakapulana. (NATO as a Source of Discord between the United States and France).

HY, Pol. sc., 1966.

Reino Kcro, Siirtolaisuus Satalcunnasta Amerikkaan ennen ensimmäistä maailmansotaa, 1882-1914. (The Migration from Satakunta to the United States before the First World War).

TY, General history, 1965. 143 p.

Reino Kero, Amerikan kuva Suomen sanomalendissä siirtolaisuuden alkuaikoina. (The Image of the United States in the Finnish Press during the Early Period of Migration).

TY, Finnish history, 1968, 111 p.

Osmo Kiiskinen, Siirtokuntien kaapparit Yhdysvaltain vapaussodassa vv. 1775 -1783. (The Colonial Raiders in the War for Independence, 1775-1783).

HY, Gcneral history, 1968.

Pentti Kiislcinen, Meksikon ongelma Woodrow Wilsonin poliittisessa ajattelussa. (The Mexican Problem in the Political Thought of Woodrow Wilson). HY, General history, 1966.

Eino-Olavi Koivukangas, Amerikansuomalaisen Raivaaja-lehden suhtautuminen Suomeen toisen maailmansodan aikana. (The Attitude of the American-Finnish newspaper »Raivaaja» towards Finland during the Second World War).

TY, General history, 1967. 117 p.

Peklca J. Korvenheiino, Helsingin Sanomien suhtautuminen Amerikan Yhdysvaltoihin jatlcosodan aikana vuosina
1941-1944. (The Atitude of the Finnish Newspaper »Helsingin Sanomat» towards the United States during the Continuation War, 1941-1944).

HY, Pol. sc., 1964. 142 p.

Vilho, Kuljo, Woodrow Wilsonin politiiklka Amerilrassa. (The Politics of Woodrow Wilson).

HY, General history, 1965.

Raija Kyllönen, Amerikan intellcktuellit ja kommunismi. (American Intellectuals and Communism).

HY, Pol.sc., 1967.

Pekka Laine, Förenta Staternas och Storbritanniens attityder till erkännandet av Kina och till. Kinas representation i Porenta Nationerna. (The Attitudes of the Unitrd Stater and Great Britain towards the Recognition of China and towards the Representation of China in the United Nations).

AA , Polssc., 171 p. Lic.Phil.

Tauno Lampj., Theodore Roosevelt ja Venezuelan kriisi. (Theodore Rooscvelt and the Venezuelan Crisis, 1902-1903). HY, Gcneral history, 1965.

Tapani Lausti, Yhdysvaltain ulkopolitiilrka kommunistimaihin nahden toisen maailmansodan jalkeen. (The Foreign Policy of the United States after the Second World War in Relation to the Communist Countries).

HY, Pol.sc., 1966.

Risto Lehmusvuori, Interventio Yhdysvaltain ja Latinalaisen-Amerikan välisissä suhteissa toisen maailmansodan jalkeen. (The Role of Intervention in the Relations of the United States with Latin America after the Second World War).

HY, Pol.sc., 1966.

Laila Lehtinen, Lafayetten asema Ranskan ja Amerilcan välillä vuosina 1777 -1789. (Lafayette, France and the United States, 1777-1789).

JY, General history, 1966. 112 p. 
Väinö Leinonen, Yhdysvaltojen suhtautuminen Puolan kysymykseen vuosina 1939-1943. (The United States and the Polish Question, 1939-1943).

HY, General history, 1967.

Jyrlci Lohi, Tyynen meren saaristot suurvaltain politiikassa 1898-1899. (The Isles of the Pacific in the Foreign Policy of the Great Powers, 18981899).

HY, General history, 1964. 110 p.

Eino Lonka, Pohjois-Amerikan ensimmäinen lcontinentaalinen kongressi vuonna 1774. (The first Continental Congress).

JY, General history, 1965. 80 p.

Pertti, Malin, Jeffersonin käsitykset Euroopan poliittisesta tilanteesta ennen Ranskan suurta vallankumousta. (The Views of Thomas Jefferson on the Political Situation in Europe before the French Revolution).

TY, General history, 1968. 170 p.

Matti Mikkilä, USA:n ulkopolitiilca ja Japani vuoen 1931 syyskuusta vuoden 1932 maaliskutuhun. (The Foreign Policy of the United States and Japan, September 1931-March 1932).

HY, General history, 1965.

Markku A. Murros, Yhdysvaltain ulkopolitiikan ja yleisen mielipiteen suhtautuminen Euroopan tilanteeseen Münchenin konferenssin ja II maailmansodan syttymisen valisena aikana 1938-1939. (The Attitudes of American Foreign Policy and Public Opinion to the Situation in Europe from the Munich Conference to the Outbreak of the Second World War, 1938-1939).

$H Y$, General history, 1965.

Erklci Nyrhinen, Juutalaiskysymyksen vaikutus Yhdysvaltain Venäjän suhteisiin ennen Venäjän vallankumousta. (The Influence of the Jewish Question on the Relations of the United States with Russia before the Russian Revolution).

JY, General history, 1967. 148 p.

Arhi Palosuo, Kanadan ja Yhdysvaltain suhteet pluralistisessa turvallisuusyhteisössä. (The Relations of Canada and the United States in the Pluralistic Security System).

HY, Pol.sc., 1966.
Irma Peiponen, Venezuelan ja brittiläisen Guyanan valinen rajakiista 1800 -luvun lopussa. (The Dispute between Great Britain and Venezuela over the Boundary of Brittish Guiana).

JY, General history, 1968. 127 p.

Pekka Pessa, Presidentti Wilsonin Venäjän-politiikka ensimmaisen maailmansodan aikana. (The Foreign Policy of President Wilson in relation to Russia during the First World War).

HY, General history, 1966.

Matti Pitkänen, Neuvostoliiton ja Yhdysvaltojen suhteet vuosina 1917-1927. (The Relations of the United States with the Soviet Union, 1917-1927).

JY, General history, 1966. 157 p.

Kari Poutasuo, Yhdysvaltojen ja Japanin suhteet toisen maailmansodan jälkeen. (The Relations of the United States with Japan after the Second World War).

HY, Pol. sc., 1966.

Leo Puurunen, Pohjois-Amerikan intiaanit uuden ajan alkupuolella varhaisimpien Amerikan historian kertomusten mukaan. (The Indians of North America as viewed in the Earliest Writings on American History).

TY, General history, 1966. 153 p.

Auli Raunio, Suomen talvisodan kuva New York Times'issa vuosina 1939.. 1941. (The Image of the Winter War in the »New York Times», 19391941).

TY, General history, 1967. 338 p.

Helena Rinta-Paavola, Thomas Jefferson ja Pohjois-Amerikan Yhdysvaltain intiaanit. (Thomas Jefferson and the Indians of the United States of America), HY, General history, 1967.

Elina Saloniemi, Benjamin Franklinin poliittiset aatteet ja niiden muodostuminen. (The Making of the Political Ideas of Benjamin Franklin).

HY, General history, 1965.

Pentti Sarpa, Yhdysvaltain ja Neuvostoliiton suhteet Kiinaan vuodesta 1931 Japanin antautumiseen. (The Relations of the United States and the Soviet Union with China from 1931 to the Surrender of Japan).

HY, General history, 1964. 
Pirkko Sirkiä, Suurlähettiläs Page ja Yhdysvaltain asenne ensimmaiseen maailmansotaan. (Ambassador Page and the Attitude of the United States to the First World War).

TY, General history, 1966. 119 p.

Ritva Teijonsalo, Neekerien yhteiskunnallinen asema Etelävaltioissa 18631890. (The Social and Political Status of the Negro in the South, 1863-1900). HY, General history, 1966.

Matti Telemäki, Yhdysvaltain presidentinvaalit vuonna 1960. (The Presidential Elections of 1960).

TaY, Pol.sc., 1965. 92 p.

Ulla Tuominen, Amerikan kaupunki 1600-luvulla eaglantilaisissa siirtokunnissa. (The American Town in the British Colonies in the 17th Century).

HY, General history, 1967.

Roy Wenman, Om den transoceana emigrationen från Närpes 1900-1930. (The Overseas Migration from the $\mathrm{Pa}$ rish of Närpes, 1900-1930).

HY, General history, 1967.

Antero Viertio, John Foster Dullesin käsitykset USA:n ulkopolitiikan päämääristä ja hanen käytännön toimin- tansa niiden saavuttamiseksi. (The Views of John Foster Dulles on Aims of American Foreign Policy and his Efforts to achieve them).

RY, Pol.sc., 1967.

Teuvo Vikman, Länsi-Saksa Yhdysvaltain liittolaisena vv. 1955-1967. (West Germany as an Ally of the United States, 1955-1967).

HY, Pol.sc., 1968.

Osmo Virrantola, Thomas Painen hallitusmuotokäsitylkset. (The Constitutional Ideas of Thomas Paine).

JY, General history, 1965. 113 p.

Abbreviations:

HY = University of Helsinki

$\mathrm{JY}=$ University of Jyväskylä

TaY $=$ University of Tampere

$\mathrm{TY}=$ University of Turku

$\AA \mathrm{A}=$ Abo Akademi

Source:

hi

Bibliography of Master's and Lic. P 1. Theses concerning General History in Finland. Institute of General History, Univ. of Turku. 